\title{
Editorial
}

\section{The early history of netting bats}

The Japanese-style mist net that mammalogists and ornithologists use extensively came into regular use by scientists in the 1950s and early 1960s and its use in capturing bats and birds unharmed is now worldwide. The history of the innovative mist net, which was originally made of silk and brought to the U.S. by ornithologist Oliver L. Austin, Jr., shortly after WW II, was reviewed recently by Genoways et al. (2020). However, the mist net was not the first net to be used for the scientific capture of bats and birds - that was the Italian trammel net.

The Italian trammel net had a long history of being used to capture birds for culinary purposes (Macpherson 1897). The Italian Peninsula, like the prefectures along the coast of the Sea of Japan where the Japanese kasumi-ami net is believed to have been developed in the middle of the 17th century, is along one of the major migratory flyways between Europe and Africa.

Apparently, the first biologists to successfully use a net to capture bats were Josselyn Van Tyne and Adolph Murie, then at the University of Michigan, Ann Arbor. In 1931, Van Tyne and Murie worked together sampling birds and mammals at the Uaxactún Mayan archaeological site in north-central Guatemala. Prior to departure on this trip, ornithologist Oliver L. Austin, Jr., loaned Van Tyne a linen trammel bird net that Austin had imported from Italy.

Van Tyne's primary goal in Guatemala was to collect birds (Van Tyne 1935), but he left the trammel net in place overnight, catching bats serendipitously, with the first capture being on 13 April 1931. Over the next month, he and Murie captured 55 bats representing four genera and five species of phyllostomids (Artibeus, Carollia, Desmodus, and GlossophagaVan Tyne 1933). Adolph Murie included the bats taken with Van Tyne using the trammel net in his report on the mammal survey in Guatemala and Belize (Murie 1935). Although this is almost certainly the first time a net was used to catch bats that were preserved as scientific specimens, it was not an innovation that changed mammalogy because the use of trammel nets seemingly was not embraced by others.

Francesco Chigi (1933) first described the use of the trammel net to catch birds for banding in Italy (Figure 1). Chigi (1933:59) stated, "For taking birds in nets special skill is necessary, besides a knowledge of the habits of the different species, hence only the most expert bird-catchers are able to use nets with the maximum of efficiency."

Trammel nets were of varying lengths, with the one used by Van Tyne and Murie being 40 feet long by 6 feet high. Those described in Chigi (1933) look longer and taller. Trammel nets distinguish themselves from other sorts of nets because instead of a single wall (or brail) of netting, they have two or more walls, sometimes constructed of different materials as well as varying sizes of mesh. The two outside nets are made of strong cotton or linen with a mesh size of $35 \mathrm{~cm}$ by $25 \mathrm{~cm}$ (Chigi 1933) or 7 inches by 7 inches (Van Tyne 1933), whereas the single internal net was made of the same material but lighter and finer textured, with mesh sizes of $3.5 \mathrm{~cm}$ by $2.5 \mathrm{~cm}$ (Chigi 1933) or 0.75 inch by 0.75 inch (Van Tyne 1933). All three nets were suspended by metal rings along a heavy rope or cord stretched between two trees or stout poles. The outer trammels were slightly flared and staked to the ground and kept taut, but the inner net was allowed to hang freely. Van Tyne (1933:145) warns that under the nets, "clear completely a 'right of way' ... leaving the ground bare. If this is not done thoroughly, much time will be wasted later in disengaging twigs and leaves from the net." The concept was that any bird or bat approaching the net would fly through the first outer net, strike the middle net forming a pocket, and this pocket would loop through the second outer net holding the captured individual tightly.

Philip Hershkovitz, who was a graduate student in mammalogy at the University of Michigan in the early 1930s and again in the late 1930s, would have known of Van Tyne's and Murie's success in capturing bats with the trammel net in Guatemala. He wrote in 1986 that the trammel net was known as early as the early 1800 s but had not been used in fieldwork (Hershkovitz 1987). The fact that four articles appeared in just a three-year period in the mid 1930s in both the ornithological and mammalogical literature, but did not result in the adoption of nets to collect bats and birds is a historical enigma. To add to this mystery, Van Tyne (1935:9) reported that the net they used in Guatemala was loaned to him by his friend, "Oliver L. Austin, Jr., of the United States Biological Survey." This is, indeed, the same Oliver Austin who, a little more than a decade later, set off the widespread use of Japanese mist nets (Genoways et al. 2020). In the 1930s, the U.S. Biological Survey had active collecting programs in both mammals and birds, but clearly, the trammel net was not widely adopted. A partial answer to our mystery may lie with the complicated three-layer design of the trammel nets. 


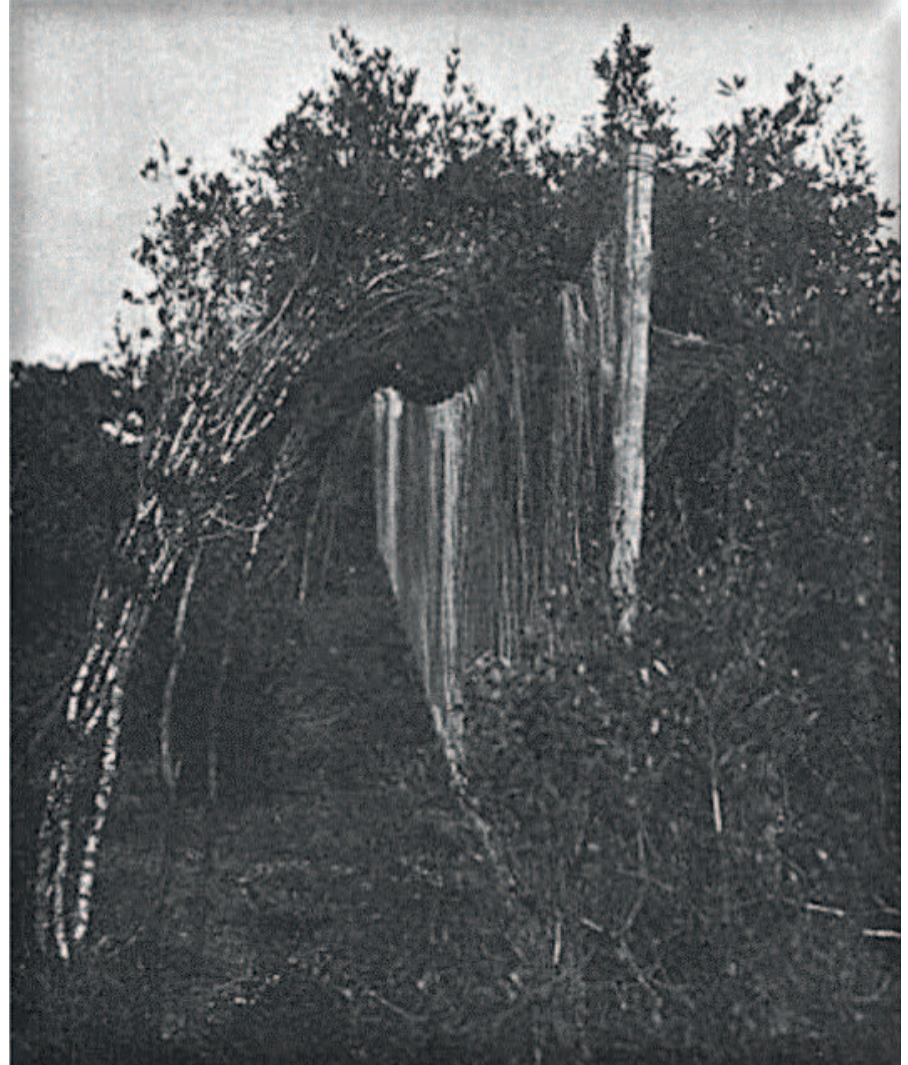

Figure 1. A trammel net set about fifteen miles from Rome in a corridor at the Station of Castel Fusano, founded through the National Fascist Federation of Italian Sportsmen. Modified from Chigi (1933:63, figure 2). The long light net in the center of the photo is one of the outside cotton or linen nets; a thinner, lighter net can be seen to the right of the post. Note the well-cleaned net lane and stout post anchoring the end of the net.
Another reason for the non-adoption of the trammel net may lie with bad timing. In the U.S., the stock market had crashed in 1929, Franklin Roosevelt was elected President in 1933 to combat the Great Depression, and the Dust Bowl was in full swing, with World War II beginning to loom in Europe. Adolph Hitler became chancellor in Germany in 1933, Italy under Mussolini invaded Ethiopia in 1935; in 1932 Japan annexed a portion of Manchuria and the seeds of war with China were planted. When Austin (1947) described the use of Japanese mist nets, the war was over. He was familiar with the Italian trammel net and the mist net, and it was the mist net that he shared with his colleagues in 1950. It was the post-World War II publications introducing the kasumiami Japanese-style mist net that had an immense impact on mammalogy and ornithology (Austin 1947; Dalquest 1954; Clench and Hardy 1989; Genoways et al. 2020). There was a boom in higher education in the U.S. as returning veterans took advantage of the G.I. Bill. A cohort of these new students had been exposed to medical and other scientific aspects of war, resulting in pursuit of careers in mammalogy, ornithology, parasitology, and other scientific fields. The timing was right, Japanese mist nets were becoming available, and were easier to set and manage although, being imported from Japan, they were not always readily available and somewhat expensive. Tom Kunz (2005:159) informs us that in the mid-1960s, his first mist nets were purchased for "about \$8.00 each" [about \$66.00 in 2021 dollars].

\section{Acknowledgments}

David Huckaby provided insights into the early history of the use of trammel nets and Cody Thompson and Brett Benz provided background on the Museum of Zoology, University of Michigan's records. Ed Heske critically reviewed an earlier draft of this manuscript. The photograph of the trammel net used as Figure 1 was edited by Matthew Girard to compose the figure.

Robert M. Timm ${ }^{1 *}$ Suzanne B. McLaren², and Hugh H. Genoways ${ }^{3}$

${ }^{1}$ Department of Ecology \& Evolutionary Biology and Biodiversity Institute, University of Kansas, Lawrence, KS 66045 U.S.A. Email: btimm@ku.edu (RMT). ${ }^{2}$ Section of Mammals, Edward O'Neil Research Center, Carnegie, Museum of Natural History, Pittsburgh, PA 15206 U.S.A. Email:McLarenS@CarnegieMNH.Org (SBM).

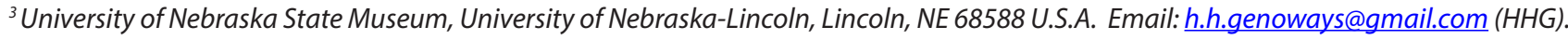

*Corresponding author

\section{Literature cited}

Austin, O. L., JR. 1947. Mist netting for birds in Japan. General Headquarters, Supreme Commander for the Allied Powers, Natural Resources Section Report, Tokyo 88:1-24.

CHIGI, F. 1933. Methods of capturing birds at the ornithological station Castel Fusano, Italy. Bird-Banding: A Journal of Ornithological Investigation 4:59-67 (translated into English from Italian by Margaret Morse Nice, a prominent ornithologist of the era).

Clench, M. H., AND J. W. Hardy. 1989. In Memoriam: Oliver L. Austin, Jr. Auk 106:706-723.

Dalquest, W. W. 1954. Netting bats in tropical Mexico. Transactions of Kansas Academy of Science 57:1-10.

Genoways, H. H., S. B. McLaren, AND R. M. Tımm. 2020. Innovations that changed mammalogy: the Japanese mist net. Journal of Mammalogy 101:627-629.

Hershrovitz, P. 1987. A history of the recent mammalogy of the Neotropical region from 1492 to 1850. Pp. 11-98 in Studies in Neotropical mammalogy: essays in honor of Philip Hershkovitz (Patterson, B. D., and R. M. Timm, eds.). Fieldiana: Zoology (New Series) 39:viii + 1-506.

Kunz, T. H. 2005. Becoming a mammalogist: on the wings of heroes. Pp. 141-170 in Going afield: lifetime experiences in exploration, science, and the biology of mammals (Phillips, C. J., and C. Jones, eds.). Museum of Texas Tech University, Lubbock, Texas. 
MaCPherson, H. A. 1897. A history of fowling. David Douglas. Edinburgh, Scotland.

Murie, A. 1935. Mammals from Guatemala and British Honduras. Miscellaneous Publications of the Museum of Zoology, University of Michigan 26:1-30.

VAN TYNE, J. 1933. The trammel net as a means of collecting bats. Journal of Mammalogy 14:145-146.

VAN TYNE, J. 1935. The birds of northern Petén, Guatemala. Miscellaneous Publications of the Museum of Zoology, University of Michigan 27:1-46. 
4 THERYA Vol. 12 (1): 1-3 